\title{
NF-Kappa-B Inhibitor Beta
}

National Cancer Institute

\section{Source}

National Cancer Institute. NF-Kappa-B Inhibitor Beta. NCI Thesaurus. Code C38395.

NF-kappa-B inhibitor beta (356 aa, $\sim 38 \mathrm{kDa}$ ) is encoded by the human NFKBIB gene. This protein is involved in the regulation of nuclear factor kappa-B-mediated gene transcription. 